\title{
Development of Learning Tools Oriented Problem Based Learning Models Assisted by Macromedia Flash to Improve Mathematics Literacy Ability of Class X High School Students
}

\author{
Mohd. Zulfachri Fadli Ritonga ${ }^{1} \quad$ Izwita Dewi $^{2} \quad$ Yulita Molliq Rangkuti $^{3}$ \\ State University of Medan, Jl. Willem Iskandar Psr. V Medan, Indonesia
}

\begin{abstract}
This research aims to: Analyzing the validity, practicality, and effectiveness of learning tools oriented towards problem-based learning models assisted by macromedia flash that was developed to improve students' mathematical literacy skills. The ability of mathematical literacy using the developed learning device increased, in terms of the N-Gain Score The Mathematics Literacy Ability Test increased in Trial I reaching 0.38, increasing to 0.43 in Trial II and increasing to 0.51 at the deployment stage.
\end{abstract}

Keywords: Development of Learning Tools, Problem Based Learning Models, Mathematics Literacy Ability.

DOI: $10.7176 / \mathrm{JEP} / 11-15-09$

Publication date:May $31^{\text {st }} 2020$

\section{PRELIMINARY}

The world of Indonesian education in the 21 st century is being faced with two major problems, namely the low quality of education and inadequate learning systems in schools. This is in line with the statement of Stein B, an American representative in Medan (Raz, 2008: 376 in Hasratuddin, 2013: 131) which says that "At present the condition of the Indonesian people is facing a serious problem relating to very low morality in both cities and villages, like there is no courtesy, no norms, "shortcuts are deemed appropriate" ${ }^{[5]}$.

Education is a means of preventing risks, as well as tools that can help improve the quality of human life in a sustainable manner. Sari $(2015: 713)$ said that education today is expected to be able to develop students to think creatively, flexibly, solve problems, collaborative and innovative skills needed to succeed in work and life ${ }^{[12]}$.

This ability is expected to be developed in education through subjects taught in schools. Based on the 2013 curriculum content standards, mathematics is a subject that must be learned at school.Cockroft's opinion (Abdurrahman, 2003: 253) states that mathematics needs to be taught to students because it is always used in terms of life, all requiring mathematical and mathematical skills can improve logical thinking abilities ${ }^{[1]}$.

One characteristic of mathematics is that it has abstract objects. This abstract nature causes many students to experience difficulties in learning mathematics.

From the results of Indonesia participated in the PISA (The Program for International Student Assement) from 2000 to 2015 with results that did not show much change in each of its participation. In 2015 Indonesia was ranked 69 out of 76 countries with a score of 386 with an average score of 490 (PISA, 2015: 1). One of the aspects of assessment conducted by PISA (The Program for International Student Assement) is mathematical literacy. Where, the ability of mathematical literacy is the ability of individuals to formulate, use, and interpret mathematics in various contexts which include mathematical reasoning and the use of mathematical concepts, procedures, facts and tools.in solving everyday problems.

To solve existing problems, a solution is needed to overcome it, one of them is by developing learning tools. The purpose of the developed learning device is to obtain good student learning outcomes in mathematics and can improve students' mathematical literacy abilities. Thus the development of learning tools is a process to determine or create a certain condition that causes students to interact so that changes in behavior occur. Implementing the development of teaching devices required development models that are compatible with the education system. One of them is the Four-D learning development model (define, design, develop, and disseminate), suggested by Sivasailam Thiagarajan, Dorothy S. Semmel, and Melvyn I. Semmel (1974: 5).

To help facilitate students in learning, there are various kinds of media that can be used in Mathematics learning. One of them is Macromedia flash. Macromedia flash animation program is a presentation media that is designed using technological developments ${ }^{[14]}$. Samsyuar (2018: 3) sayslearning innovations carried out in the development of digital information technology are utilizing information technology facilities that are growing rapidly in the era of the industrial revolution $4.0^{[11]}$.

According to Gerlach \& Ely (Asyhar, 2012: 8-9), learning media has a very broad scope, which includes humans, material, or studies that build a condition that makes students able to obtain knowledge, skills or attitudes $^{[2]}$. With the learning media, the author wishes to collaborate the problem-based learning model with Macromedia Flash which is expected to be more helpful in facilitating the teaching of Mathematics and increasing the ability of teachers to interact with the media. 


\section{LITERATURE REVIEW}

\section{The Nature of Mathematics Learning}

Simple learning can be interpreted as an attempt to influence one's emotional, intellectual, and spiritual so that they want to learn with their own will (Nata, 2009: 85) ${ }^{[7]}$. Meanwhile, according to Sagala (2009: 62) learning as a learning process is built by the teacher to develop thinking creativity that can improve students' thinking abilities and can improve the ability to construct new knowledge in an effort to increase good mastery of the subject matter ${ }^{[10]}$.

So it can be concluded that the nature of mathematics learning is a learning process that is built by the teacher to improve mathematical abilities in solving mathematical problems that involve in everyday life and can improve thinking abilities, creativity abilities, ability to construct knowledge and problem solving abilities

\section{Learning Media}

Learning material or learning material, is teaching material that is packaged as material to be presented in the learning process. Learning tools needed in managing the teaching and learning process can be in the form of: syllabus, Learning Implementation Plan (RPP), Student Activity Sheet (LKS), Evaluation Instrument or Learning Outcomes Test (THB), learning media, and student textbooks (Trianto, 2010: 201) ${ }^{[15]}$.

\section{Mathematical Literacy Ability}

Literacy is an absorption of the English word "literacy" which means literacy or the ability to read and write. According to the 2015 PISA draft assassment, PISA defines mathematical literacy abilities as follows,

"Mathematical literacy is an individual's capacity to formulate, employ, and interpret mathematics in a variety of contexts. It includes mathematical reasoning and using mathematical concepts, procedures, facts and tools to describe, explain and predict phenomena. It assists individuals to recognize the role that mathematics plays in the world and to make the well-founded judgments and decisions needed by constructive, engaged and reflective citizens. "[8] (OECD, 2013: 25).

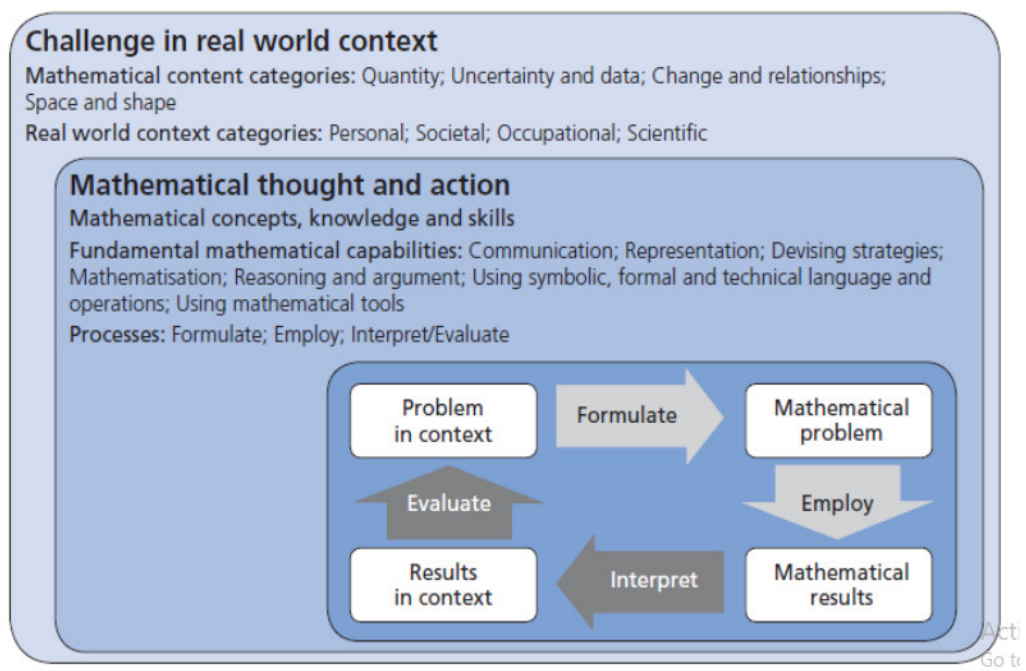

Figure 1. Mathematical Literacy Model in Practice (OECD, 2013: 26)

More simply, Ojose (2011: 89) argues that mathematical literacy is knowledge to know and use the basis of mathematics in everyday life ${ }^{[9]}$

\section{Problem Based Learning Model}

Bahriah (2015: 15) says that problem-based learning model is one of the learning models that presents contextual problems that can stimulate the creativity of students to find concepts and solve problems in everyday life ${ }^{[3]}$. According to Dewey (in Trianto 2009: 91) "learning based on problems is the interaction between stimulus and response, is the relationship between two directions of learning and the environment".

\section{Macromedia Flash Learning Media}

Gagne (in Ashyar, 2012: 45) states that the media are various types of components in the student environment that can stimulate them to learn. According to Suparman (in Sutikno, 2013: 31) media is a tool used to channel messages or information from the sender to the recipient of the message ${ }^{[13]}$. From the description above it can be concluded that the media is a tool used to convey information from one person to another so that it can stimulate one's thoughts, feelings and interests.

According to Jayadi (2008: 37) Macromedia Flash is a software program that presents audiovisual messages 
clearly to students and material that is real, so that it can be illustrated more attractively to students with a variety of animated images that can stimulate student interest in learning to achieve learning goals ${ }^{[6]}$. Furthermore according to Prasetio in Cahyo (2013: 52) Macromedia Flash is an animation software that can be used to facilitate the delivery of an abstract concept in its application using a computer and media imager projector ${ }^{[4]}$.

\section{RESEARCH METHOD}

This study uses the Thiagarajan 4-D development model (define, design, develop, and disseminate). This development is carried out to produce problem-based learning tools assisted by Macromedia Flash which will then be tested in class using The One-Group Pretest-Posttest Design, by not using a comparison class but using Pretest so that the magnitude of the increase in students' Mathematics Literacy ability can be known with certainty. This research will be conducted at SMA Negeri 1 Kualuh Hulu located in Aekkanopan, Labuhanbatu Utara in class X science 2 and X science 3 odd semester 2019/2020 Academic Year.

\section{RESULTS}

This research is a development research (development research). The product developed in this study is a learning device so that it meets valid, practical and effective criteria. The learning tools developed include the lesson plan (RPP), teacher's book (BG), student's book (BS), and student activity sheets (LKPD). Learning tools were developed using the 4-D development model from Thiagarajan. which includes four stages, namely definition, design, development and dissemination

Mathematical Literacy Ability of students can be seen from the ability of students in mathematical literacy of students based on PISA levels which are divided into 6 levels or 6 levels. The analysis of the results of mathematical literacy ability Test I based on each level of mathematical literacy ability is shown in the following figure.

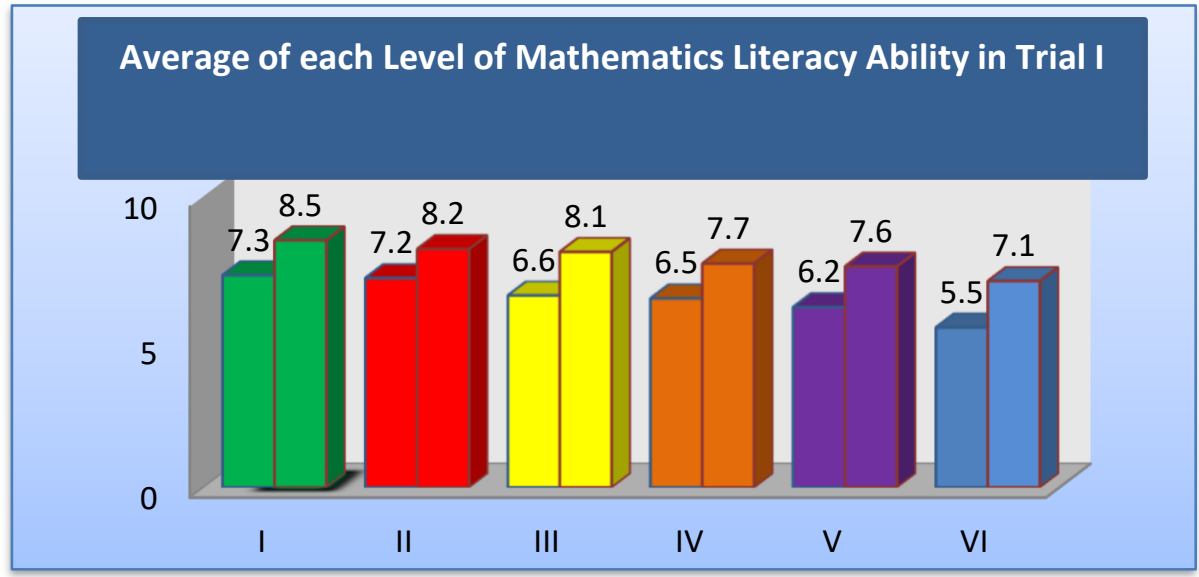

Figure 2. Average of each Level of Mathematics Literacy Ability in Trial I

From Figure 2 above the average mathematical literacy ability shows that there is an increase in each level of mathematical literacy ability. The highest increase is 1 and 6 which is at level 6 namely: Using reasoning in solving mathematical problems, can make generalizations, formulate and communicate the findings. While the lowest increase is at level 2, 1 .

Furthermore, the results of completeness of students' mathematical literacy skills in the first try can be seen in Table 1

Table 1. Completeness Level Pre-Test and Post-Test Mathematical Literacy Ability in the Deployment Stage of Trial I

\begin{tabular}{|c|c|c|c|c|}
\hline \multirow[b]{2}{*}{ Category } & Pre-Test & \multirow{2}{*}{$\begin{array}{c}\text { Classic Mastery } \\
\text { Percentage }\end{array}$} & Post-Test & \multirow{2}{*}{$\begin{array}{c}\text { Classic Mastery } \\
\text { Percentage }\end{array}$} \\
\hline & $\begin{array}{c}\text { Total } \\
\text { students }\end{array}$ & & $\begin{array}{c}\text { Total } \\
\text { students }\end{array}$ & \\
\hline Complete & 11 & $30.56 \%$ & 32 & $88.89 \%$ \\
\hline Not complete & 25 & $69.44 \%$ & 4 & $11.11 \%$ \\
\hline Amount & 36 & $100 \%$ & 36 & $100 \%$ \\
\hline $\begin{array}{c}\text { Class } \\
\text { Average }\end{array}$ & 66.2 & & 80.7 & \\
\hline
\end{tabular}

From table 1. above can be seen that the classical completeness of mathematical literacy skills in the pre-test in trial Iis 11 people out of 36 people $(30.56 \%)$ with a class average of 66.2, while the classical completeness of students' mathematical literacy skills in the post-test I trial 32 people out of 36 people $(88.89 \%)$ with a class average 
of 80.7

As for the second trial, the analysis of the results of the ability of mathematical literacy Test II based on each level of mathematical literacy ability is shown in the following figure.

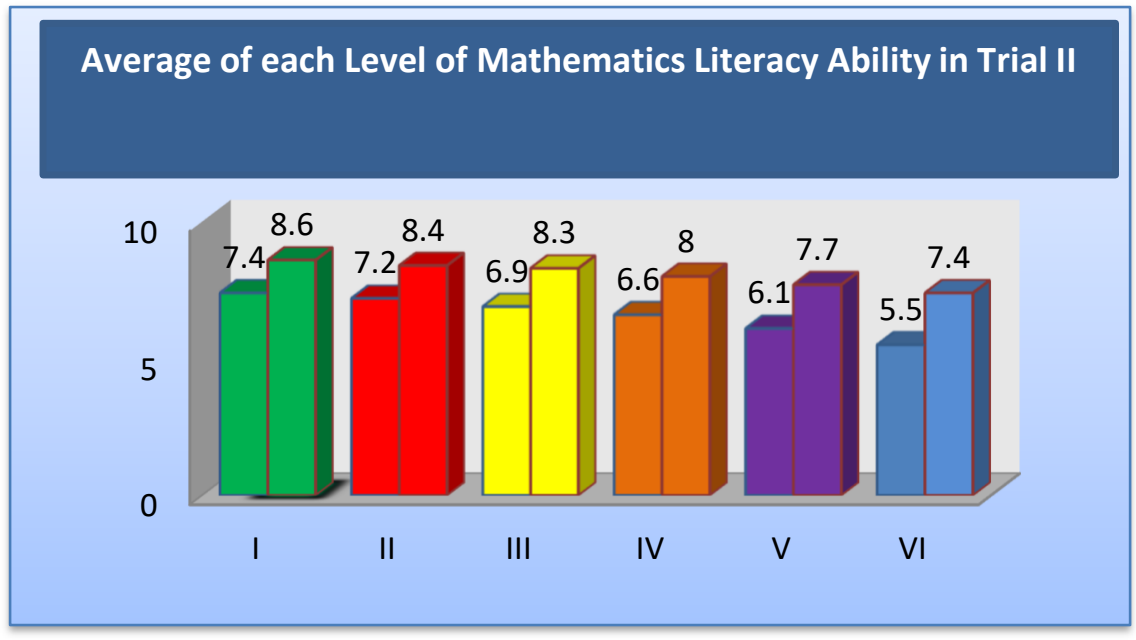

Figure 3. Average of each Level of Mathematics

Literacy Ability in Trial II

From Figure 3 above the average mathematical literacy ability shows that there is an increase in each level, it can be seen that from the average mathematical literacy ability, it shows that there is an increase in each level of mathematical literacy ability. Furthermore, the results of completeness of students' mathematical literacy skills in the second trial phase can be seen in Table 2

Table 2. Completeness Level Pre-Test and Post-Test Mathematical Literacy Ability in Phase Deployment of Trials II

\begin{tabular}{|c|c|c|c|c|}
\hline \multirow{2}{*}{ Category } & Pre-Test & \multirow{2}{*}{$\begin{array}{c}\text { Classic } \\
\text { Mastery } \\
\text { Percentage }\end{array}$} & $\begin{array}{l}\text { Post- } \\
\text { Test }\end{array}$ & \multirow{2}{*}{$\begin{array}{c}\text { Classic } \\
\text { Mastery } \\
\text { Percentage }\end{array}$} \\
\hline & $\begin{array}{c}\text { Total } \\
\text { students }\end{array}$ & & $\begin{array}{c}\text { Total } \\
\text { students }\end{array}$ & \\
\hline Complete & 12 & $33.33 \%$ & 33 & $91.67 \%$ \\
\hline $\begin{array}{c}\text { Not } \\
\text { complete }\end{array}$ & 24 & $66.67 \%$ & 3 & $8.33 \%$ \\
\hline amount & 36 & $100 \%$ & 36 & $100 \%$ \\
\hline $\begin{array}{c}\text { Class } \\
\text { Average }\end{array}$ & 65.9 & & 83.2 & \\
\hline
\end{tabular}

From table 2 above it can be seen that the classical completeness of mathematical literacy skills in the pretest at the trial phase IIis as many as 12 people out of 36 people $(33.33 \%)$ with a class average of 65.9 , while the classical completeness of students' mathematical literacy skills in the post-test deployment stage is as much 33 people out of 36 people $(91.67 \%)$ with a class average of 83.2 .

\section{Classical Mathematical Literacy Capabilities Achieved}

The following will describe the percentage of students who achieved completeness for each meeting in trial I, trial II and the stages of deployment in table 2 below.

Table 3. Classical Completeness Analysis Results in Trial I, Trial II and Dispersal stage

\begin{tabular}{|c|c|c|c|}
\hline Category & Trial I & Trial II & Dissemination Stage \\
\hline Complete & $80.56 \%$ & $88.89 \%$ & $91.67 \%$ \\
\hline Not complete & $19.44 \%$ & $11.11 \%$ & $8.33 \%$ \\
\hline Average Value & 78.8 & 81.0 & 83.2 \\
\hline
\end{tabular}

From Table 3 above can be seen that in the first trial, the average Post-test mathematics literacy ability of students was 78.8 with the percentage of students who achieved a value of $80.56 \%$. The results obtained do not meet the established classical achievement criteria, i.e $\geq 75 \geq 85 \%$. From the learning process that is observed and the students' activities in solving the given problem, it is used as a reference to the revision of the learning device for trial II. Furthermore, the average Post-test mathematics literacy ability of students in the second trial 
was 81.0 with the percentage of students achieving grades of $88.89 \%$. From these results it appears that the classical achievement criteria have been met. $\geq 75$ Furthermore, the average Post-test mathematics literacy ability of students at the deployment stage was 83.2 with the percentage of students achieving grades of $91.67 \%$. From these results it appears that the classical achievement criteria have been met. $\geq 75$

\section{REFERENCES}

Abdurrahman, M. (2003). Education for Children with Learning Difficulties. Jakarta: Rineka Cipta.

Asyhar, R. (2012). Creative Developing Learning Media. Jakarta : Gaung Persada (GP) Press

Bahriah, ES (2015). Improvement of Science Literacy for Prospective Chemistry Teachers in Aspects Context of Application and Science Process. EDUSAINS Journal, 7 (1), 11-17.

Cahyo, NA (2013). Application Guide to the Most Active and Most Popular Teaching and Learning Theories. Yogjakarta: Diva Press

Hasratuddin. (2013). Building Character Through Mathematics Learning. Journal of Mathematics Education PARADIKMA, 6(2), 130-141 . (2015). Why Study Math? Medan: Prime Publishing.

Jayadi. (2018). Macromedia Flash Learning Media Design and Application. Jakarta: Ardana Media.

Nata, A. (2009). Islamic Perspective on Learning Strategies. Kencana: Jakarta.

OECD (2013). PISA 2012 Mathematics Assessment and Analytical Framework,Reading, Science, Problem Solving and Financial Literacy. OECD Publishing.

Ojose, B. (2011). Mathematics for Literacy: Are We Able to put The Mathematics We Learn Into Everyday use? Journal of Mathematics Education, 4 (1), 89-100.

Sagala, Syaiful. (2009). Concepts and Meanings of Learning. Bandung: ALFABETA

Samsyuar \& Reflianto. (2018). Education and Learning Challenges Based on Information Technology in the Industrial Revolution Era 4.0. E-Tech Journal Scientific Educational Technology, 6 (2), ISSN 25415948 (Online).

Sari, RHN (2015). Mathematical Literacy: What, Why and How? UNY Mathematics Education. ISBN: 978-60273403-0-5, p. 713-720.

Sutikno, S. (2013). Study and Learning. Lombok: Holistica

Thiagarajan, S., Semmel, DS, \& Semmel, MI, (1974). Instructional Development For Training Teachers of Exceptional Children. Indiana:Indiana University Bloomington.

Trianto. (2009). Designing Progressive Innovative Learning Models. Jakarta: Kencana Prenada Media Group (2010). Integrated Learning Model. Jakarta: Earth Literacy 